\title{
Mediation as an Alternative of Criminal Case Resolution in Kosovo Juvenile Criminal Proceedings
}

\author{
Azem Hajdari \\ Professor at University of Prishtina "Hasan Prishtina" \\ Aktash, st. "Lord Bajron” Pristina, 1000, Kosovo \\ Tel: 383-4482-0012Ｅ-mail: azemhajdari@outlook.com
}

Received: December 2, 2017 Accepted: March 5, 2018 Published: March 7, 2018

doi:10.5296/ijsw.v5i1.12785 URL: http://doi.org/10.5296/ijsw.v5i1.12785

\begin{abstract}
Mediation is a law institute which enables alternative resolution of a criminal case between the subjects of law outside of court. It may be applicable except in criminal proceedings in which are adjudicated adults perpetrators of criminal offences, also in juvenile criminal proceedings. Through application of this institute is aimed to help the parties (to minor and the injured party) to achieve the resolution of a criminal case in the most functional manner and in accordance with their best interests. The importance of mediation is diverse. It effects in reducing the number of court cases awaiting resolution, reducing public expenditures, raising the level of social responsibility, educating citizens with the feeling of seeking forgiveness and compensation of damage, as well as cooperation with criminal procedure bodies, eliminating cases of vigilantism etc. Mediation is constituted of numerous characteristics which make it a "sui generis" institute in criminal case resolution alternatives.

Modest results of this scientific paper indicate that this institute in Kosovo courts and prosecutions concerning juvenile criminal proceedings is applicable in a very few cases. Causes of this situation may refer to the fact of not knowing the advantages of applying this institution by juvenile judges and prosecutors, but also due to the fact this institute has similarities with diversity measures, which are more preferred to be imposed against juveniles.
\end{abstract}

Keywords: Mediation, Mediator, juvenile, Prosecutor, Judg

\section{Introduction}

Mediation is a law institute through application of which is aimed to help minor and the injured party in order to achieve the resolution of a criminal case outside of court. This institute provides a better protection of parties' interests, prevents the expansion of conflicts, improves communication and promotes the development of prospective processes for them. 


\section{MInstitute Macrothink $_{\text {Int }}$}

Mediation as an alternative of criminal case resolution in Kosovo juvenile criminal proceedings may be authorized despite the gravity of committed criminal offence, but only in cases when this procedure is estimated to be appropriate for application, always by bearing in mind the nature of criminal offence, the circumstances of its commission, the history of juvenile, the possibility of returning normal relationships between juvenile and the injured party, the possibility of reducing harm of the injured party and the possibility of rehabilitating the minor and reintegrating him into society.

The initiative to enforce mediation institute in Kosovo juvenile criminal proceedings may be undertaken by the juvenile, the injured party, juvenile judge or prosecutor, whereas it shall be applicable by an independent mediator. Mediation in juvenile criminal proceedings includes numerous characteristics such as it is raised at the level of a "sui generis" institute of criminal case resolution. These specifics are of a general character, but also of specific character being present only in juvenile criminal proceedings. As shall be seen in the following handling of this scientific paper, this institute in Kosovo juvenile criminal proceedings, regardless of advantages has been applicable in a very few cases.

During the preparation of this article I have used legal, comparative, theoretical and statistical methods.

\section{Meaning of Mediation in Juvenile Criminal Proceedings}

Mediation is a criminal law institute which enables alternative resolution of criminal cases between subjects of law outside of court (Hajdari \& Krasniqi, 2012). This institute, in addition to criminal proceedings where are adjudicated adult perpetrators of criminal offences, is applicable also in juvenile criminal proceedings (Latifi \& Elezi, \& Vasilika, 2012). Mediation aims to repair damages caused by criminal offenses to the victim of crime. It is concretized as a result of the active cooperation and communication of the parties involved in process (the victim, the juvenile defendant and mediator) as well as through other forms of restorative justice (Elezi, 2015b). Mediation as the most common practice of restorative justice aims to help juvenile and the injured party to achieve functional solutions that are in favor of their common interests, to prevent the expansion of conflicts between them, to improve communication and to promote developing prospective processes for them (Shegani, 2014). In fact, mediation is negotiation between the parties with involvement of a third person - the mediator, who through neutral attitudes informs the parties that this is their dispute and they are capable of resolving the conflict (Hajdari, 2016a). Mediation is often described as the path of scale - scale creation of order and cooperation between the parties. Thus, if all issues that are part of the conflict are resolved through mediation, it is more likely that what has been achieved and completed shall withstand the test of time. As it results, in mediation procedure the juvenile and victim by expression of their free will reach an agreement concerning the existing conflict and for compensation of damage inflicted by criminal offence.

Mediation as an alternative of conflict resolution between the victim and juvenile has also found support in the guidelines and recommendations of the United Nations and the Council of Europe (Sahiti \& Murati, 2013). Among the UN documents attributing the guidelines of this nature, it is worth pointing out: Tokyo Rules (1990), the Hawaiian Rules (Resolution, 1990a), the Riyadh Guidelines (Resolution, 1990b), the Beijing Rules (Resolution, 1985), and 


\section{MInstitute Macrothink $_{\text {Int }}$}

the Guide to Action on Children in the Criminal Justice System (Resolution, 1997). Meanwhile, within the Council of Europe guidelines related to this issue it is worth mentioning recommendations no. (1992) 22, (2000) 22, (2003) 22, (1997) 12, (1999) 22 and (1999) 19.

Mediation as a criminal law institute has a long history. It is known almost by all unwritten laws, including Albanian customary law (Sahiti, 1999). Also, contemporary societies, almost without exception, recognize this institute of criminal case resolution. It is known also by Kosovo Criminal Code (Criminal Procedure Code (Article 232) (Code, No.04 / L-123), the Juvenile Justice Code (Code No. 03 / L-193) and the Law on Mediation (Law No.03 / L-057).

\section{The Importance of Mediation in Juvenile Criminal Proceedings}

Mediation institute in juvenile criminal proceedings is very important. Consequently, this institute manifests stretch of interest as in criminal procedure law (Latifi \& Elezi, \& Vasilika, 2012), in criminal law (Milutinoviq, 1984), as well as in criminal policy (Shegani, 2014). As a matter of fact, the importance of applying mediation in juvenile criminal proceedings is dealing with the fact that through this instrument:

1) Is affected in reducing the number of criminal cases proceeded in courts. Addressing criminal cases resolution during the initial review of indictment are more simple than in cases when they become subject of regular treatment in criminal proceedings, respectively through their proceeding at the main trial. (it is meant in the role of plea agreement). In these cases shall be shorten timelines of their resolution. This approach has a great criminal policy importance bearing in mind the fact in Kosovo Courts wait for resolution about 500000_cases, of which approximately $1 / 3$ of them are criminal cases among which over 1500 of them are juvenile criminal cases (Statistical Reports,..) has a great criminal-policy importance (Hajdari, 2016b).

2) Shall be shorten public money expenses which in terms of conducting regular criminal proceedings (standard) would be spent for witnesses, experts, and other lump sum expenses, which shall be estimated of a particular importance due to the fact Kosovo continues to have a very limited budget (Hajdari, 2010c).

3) Society shall be protected from re-commission of criminal offences, based on the fact that juveniles in relation to whom the mediation procedure was applicable in practice very rarely decide to commit again criminal offences, in comparison to persons against which were applicable regular criminal proceedings, regardless of judgment imposed by the court (Hajdari, 2016d).

4) It comes to better protection of the property interest of the parties (juvenile and injured party) due to the fact juvenile mediation procedure is free of charge for them. Bearing this in mind, with respective legal solutions the legislator has determined clearly that all mediation procedure expenditures referring to juveniles shall be covered by Kosovo budget.

5) Perpetrators of criminal offences shall motivate to be educated with the feeling of repenting for the committed offence, apology and compensation of damage for victims of crime. This is dictated by the fact that the mediation procedure can only be implemented in practice only if the juvenile is repented for the committed criminal offence, apologizes to the victim and indicates readiness to compensate the inflicted damage. 
6) Victims of crimes shall be motivated in cooperation with criminal procedure bodies to raise the level of communication with juvenile perpetrators of criminal offences aiming to realize easier the compensation of inflicted damage from criminal offence, of course the juvenile has its own fortune. In such cases during application of mediation procedure it comes to realization of legal-property claims easier, faster and in the manner that satisfies more the parties (juvenile and the injured party). In fact, here it is about a prosecutor or a judge who is assigned to exercise prosecution and adjudication function in juvenile department.

\section{Specifics of Mediation in Juvenile Criminal Proceedings}

As abovementioned, mediation generally and in juvenile criminal proceedings represents a criminal institute of a "sui generis" character. Being as such, it manifests numerous characteristics, among which it is worth emphasizing the following:

1) Mediation may be initiated by the minor, the injured party, the state prosecutor, and the juvenile judge. If the initiative is put into motion by the minor or the injured party, the juvenile prosecutor or judge before authorizing the mediation enforcement assess whether the legal conditions have been fulfilled and if it is reasonable the application of such institute in the particular case. As it turns out, the authority that may authorize the enforcement of mediation in juvenile criminal proceedings is the juvenile prosecutor or judge. For adult perpetrators of criminal offenses, according to the Law on Courts (Law No. 03 / L-199, Article 11), the single trial judge is the authority that adjudicates criminal cases for which the General Department of the Basic Court is competent.

2) Mediation as an alternative procedure is of optional character. This means that the state prosecutor's office or court shall only authorize this institute whenever they consider it to be appropriate for circumstances of the case. When this suitability is considered to be non-existent, then standard criminal proceedings shall be conducted.

3) By Kosovo Juvenile Justice Code there are no restrictions concerning the type of criminal offences for which mediation may be authorized. This means that mediation may be authorized for any type of criminal offences if it is considered to be appropriate by taking into account the nature of criminal offence, the circumstances of its commission, the history of juvenile, the possibility of returning normal relationships between the juvenile and the injured party, the possibility of reducing the harm of the injured party and the possibility of rehabilitating the minor and reintegrating him into society. Obviously, the application of mediation procedure is not considered appropriate for serious criminal offenses such as murders, and when they are committed in aggravating circumstances.

4) Mediation as a criminal institute may be applicable only if there is full consent between the juvenile and injured party. This implies they cannot be imposed in any way to resolve their criminal case through application of mediation institute. Therefore, if any of these subjects have any reservations concerning the initiative for mediation, the mediation cannot be implemented.

5) The mediation agreement has the power of the verdict. It produces the same effects for parties as the verdict. Thus, the agreement reached obliges the parties to fully fulfill the mutual obligations for which they are accorded. Upon its arrival, the injured party cannot 
claim the continuation of criminal proceedings. Concerning this fact he has to be notified as soon as they are instructed to mediation. On the contrary (when no agreement is reached) the criminal proceedings should continue where it has been suspended.

6) The mediation procedure is carried out by an independent mediator. Duly, he is assigned from the parties by agreement. In cases where there is no agreement between them, the mediator is appointed by the prosecutor or juvenile judge from the list of certified mediators. The mediator must be a credible, impartial and correct person. The quality of the mediator in juvenile delinquency can be attended by a lawyer, a graduate lawyer, a social worker, a pedagogue, a psychologist or a person of another profession and who is certified for mediation by the competent body.

7) The mediation procedure is limited in time, which is estimated to be very short. Consequently, the mediation procedure in juvenile criminal proceedings should be completed within 30 days, which is 60 days shorter than the criminal procedure in which adults are adjudicated. This approach is assessed to be in line with the urgent character of juvenile criminal proceedings as a rule. The juvenile prosecutor or judge must be notified of its result.

\section{Criteria for Implementation of Mediation in Juvenile Criminal Proceedings}

For implementation of mediation procedure in juvenile criminal proceedings should be fulfilled certain criteria. Consequently, as such criteria shall be considered:

1) Assessment of circumstances of a case as appropriate to be applicable to mediation procedure. These circumstances should be assessed in the context of type and nature of criminal offence, circumstances of its commission, the history of juvenile, the possibility of returning normal relationships between the juvenile and the injured party, the possibility of reducing the harm of the injured party and the possibility of rehabilitating the minor and reintegrating him into society.

2) The existence of relevant evidences proving the existence of a concrete criminal offence and the fact of its commission by juvenile. Such evidences should be available to juvenile judge and prosecutor. In this case is about evidences which make credible the fact of criminal offence existence as well as the fact that a criminal offence had been committed by juvenile.

3) Assessment of evidence on the basis of professional competence. It is a mandatory rule that juvenile judge or prosecutor prior to authorize mediation procedure application should make a detailed assessment of the evidence on the basis of which is proven the existence of a criminal offense and its connection with the juvenile. This implies that criminal case addressing in mediation procedure should be as a result of the professional assessment of evidence referring to the concrete criminal case.

These criteria implementation of mediation exist even in other Western Balkan countries such as Albania, Macedonia, Serbia etc. (Hajdari, 2013e).

\section{Subjects for Initiating and Authorizing the Implementation of Mediation in Juvenile Criminal Proceedings}

As subjects that may initiate the mediation procedure, Kosovo Juvenile Justice Code considers: the juvenile, the injured party, the juvenile prosecutor or judge. In meanwhile, as a competent body to authorize the implementation of mediation procedure in juvenile criminal proceedings, this Code considers the juvenile prosecutor or judge (Sahiti, Murati, \& Elshani, 
2014). These are subjects of the procedure to whom the offense is subject to criminal proceedings (Hajdari, 2016a).

When a juvenile prosecutor or judge is directed to send a case that is subject of criminal procedure in mediation procedure, they, according to the proposal of the juvenile and the injured person, or ex officio proceed it to an independent and neutral mediator. The appointed mediator is obliged to accept the criminal case for mediation and to take all the measures it considers necessary to ensure that the content of the agreement is proportionate to the seriousness of the case and the consequences of the criminal offense. What actions the mediator will undertake is a matter of his assessment, which should be the result of the study of the issues and interests of the parties. The mediator should help the parties to reach the agreement. This means that he has no right to impose any conditions on the parties in order to reach a settlement of the dispute. "All measures taken should aim at finally reaching an agreement between the parties. The lawmaker makes it clear that the agreement reached in each case should be the result of will of the parties (Hajdari, 213e)." Having this in mind, conflict resolution should reflect in accordance with the principle of will, impartiality, equality of parties, transparency, efficiency and justice. The mediator is also obliged to notify the juvenile prosecutor or judge of any agreement or failure to do so. This information is important because, depending on whether there is an achievement or failure of the agreement, they decide to dismiss the case or its further proceeding.

\section{Procedural Rules for Implementation of Mediation Procedure in Juvenile Criminal Proceedings}

In juvenile criminal proceedings, as abovementioned, the mediation procedure may be initiated by the juvenile, the injured party, juvenile judge or prosecutor, which may propose to them the resolution of a criminal offence through application of mediation. Juvenile judge or prosecutor may authorize the application of mediation procedure in cases when they consider that the type and nature of a criminal offence, the circumstances of its commission, the history of juvenile, the possibility of returning normal relationships between the juvenile and the injured party, the possibility of reducing the harm of the injured party and the possibility of rehabilitating the minor and reintegrating him into society shall be appropriate for mediation. In such case before the parties are instructed in mediation procedure, the juvenile prosecutor or judge shall notify them to the principles and rules of mediation as well as to the legal process and effects of the agreement reached through mediation.

When the juvenile and the injured party express their consent to mediation, this consent is put on the record and proceedings are suspended. Thereafter, from juvenile and injured party is required to arrange the mediator by agreement, and if they do not reach an agreement in this regard, the mediator shall be appointed by ruling from the juvenile prosecutor or judge from the list of certified mediators by the competent body. This ruling shall be sent to the parties and to independent mediator and he assigns to mediator obligations to contact the injured party and to then initiate the mediation procedure. Thereafter, the prosecutor or juvenile judge sends the case to the mediator who takes all necessary actions to be considered necessary in order to mark progress in reaching the agreement between the parties (Pavišić, Vučković, \& Veić \& Radolović, 1998). To achieve this goal, he has a 30-day period of time in his disposal (Elezi, 2014). In the mediation procedure, the lawmaker has prohibited any 
action that may be considered of a compelling character to the parties. This means that the agreement can be reached through mediation only with the free consent of the juvenile and the injured party. "In these cases none of the parties feel themselves gained or lost, a circumstance that gives priority to this alternative procedure in relation to the court resolution of the criminal case (Sahiti \& Murati, 2013)."

When the mediator considers necessary and in order to reach an agreement between the parties, he may conduct separate meetings with them. This situation arises especially when the parties submit unrealistic requests. In these cases it is a rule that the broker undertakes adequate measures to ensure that the content of the agreement is proportionate to the seriousness of the case and the consequences of the criminal offense (Sahiti \& Murati, 2013). In this regard, he may propose alternatives and ideas on how may a criminal case be resolved but nevertheless the parties are independent to decide definitively on the matter (Paragraphs 3 and 4 of Article 12 of the Law on Mediation). In each case when the parties reach an agreement in the mediation procedure, the mediator shall write in writing the agreement signed by the parties (the minor and the injured party) as well as the mediator himself. The agreement reached in the mediation procedure approved by the prosecutor or the juvenile judge is equivalent to the final document (court decision) and is binding for the parties (Elezi, 2015b). The mediator is obliged to inform the juvenile prosecutor or juvenile judge of the agreement and of the failure to reach the agreement, whereby he or she is notified of the reasons for such failure. Hence, upon receipt of agreement notice, the juvenile prosecutor or judge terminates the case. Whereas, if the mediator fails to reach an agreement or exceeds the 30-day deadline for its achievement, the juvenile judge or prosecutor proceeds further with such a case.

\section{Several Data on Application of Juvenile Criminal Proceedings}

Coming to sustainable conclusions and providing concrete and useful recommendations to juvenile criminal justice system bodies, mainly for juvenile prosecutors and judges, as well as for other relevant institutions and the society in general, it was necessary to research and study the work of Kosovo prosecutor's offices and courts, as well as the mediation centers in relation to mediation in juvenile criminal proceedings in Kosovo for the period of time 2013-2017.

I consider that the research of this criminal institute in terms of its practical manifestation for a period of time of five years provides possibilities which may be considered to be sufficient for the successful realization of such a goal. The presentation of the work of the state prosecutor's office, courts and mediation centers regarding the level and performance of mediation in the juvenile criminal procedure was not an easy matter. This due to the fact that in relation to their work in terms of initiation and implementation of mediation procedures during the researching period there are no published data. Such data have not been reflected nor published within reports that the Kosovo Prosecutorial Council and the Kosovo Judicial Council publish on the work of prosecutors and courts. Notwithstanding this fact, in the following handlings, the presentation of cases of criminal cases resolution in juvenile criminal proceedings through mediation shall be done on the basis of data provided by the criminal records of all prosecutions and basic courts and registers of mediation centers which currently operate in the territory of Kosovo. 
In the following in a special table, shall be presented data concerning the number of criminal cases which Kosovo basic courts and prosecutions in juvenile criminal proceedings addressed for resolution during the period of time 2013-2017.

Table1 1. Data on the number of cases referred to mediation in Kosovo juvenile criminal proceedings during the period of time 2013-2017

\begin{tabular}{llll}
\hline Years & $\begin{array}{l}\text { Number of cases referred to } \\
\text { mediation procedure by state } \\
\text { prosecutor. }\end{array}$ & $\begin{array}{l}\text { Number of cases referred } \\
\text { to mediation procedure by } \\
\text { court }\end{array}$ & $\begin{array}{l}\text { cases to mediation } \\
\text { cal referred }\end{array}$ \\
\hline $2013-26$ & 33 & 59 \\
2017 & & & \\
\hline
\end{tabular}

Note. Juvenile Registers of Kosovo's Basic Prosecutions and Courts for the period of time 2013-2017.

In meanwhile, in the following table shall be presented the number of cases conducted by mediation by independent mediators in Kosovo juvenile criminal proceedings during the period of time 2013-2017.

Table 2. Data over the number of cases resolved by mediation procedure in Kosovo juvenile criminal proceedings during the period of time 2013-2017

\begin{tabular}{ll}
\hline Years & Number of cases resolved by mediation \\
\hline $2013-2017$ & 23 \\
\hline
\end{tabular}

Note. Registers of Kosovo Mediation Centers for the period 2013 - 2017.

According to these data, during the period of time 2013-2017 Kosovo basic courts and prosecutions have referred to mediation procedure 59 criminal cases involving juveniles. Sources used indicate that basic prosecutions during the researching period have referred to mediation procedure less criminal cases involving juveniles (26) in comparison to courts (33) which in fact should be the opposite, based on the fact that Juvenile Justice Code which constitutes a specific law applicable in juvenile criminal proceedings the right to refer cases to mediation recognizes only to the state prosecution (juvenile state prosecutor - The sources used prove that during the period involved in the research at the level of the Basic Court and Basic Prosecution of Prizren only one case was referred to mediation procedure and that case also failed to be successful). From this number of cases referred to mediation, the independent mediators have reached an agreement only in 23 cases. As it results, mediation procedure has failed to be successful in 36 cases which is a concern actually (In the practice of prosecutors and judges dedication in departments there have been cases when as juvenile prosecutor and judge were appointed judges who did not have a good performance in their previous work which is in conflict with the requirements of the legislator and the entire society). This situation is estimated to be as a result of the fact that many mediators of 
country belong to a new generations of lawyers which do not have sufficient experience in terms of exercising their profession.

On the other hand, the number of cases referred to mediation (59) is extremely very small, which does not coincide with the existing practical requests and needs for application of alternative procedures in resolution of criminal cases between parties, especially when it comes to handling juveniles.

The results of this scientific paper prove that a relatively big number of criminal cases where juveniles are included, although they could have been resolved easily through application of mediation institute, did not addressed them to be resolved in this manner. This is probably due to the lack of experience, but also the lack of proper professionalism of juvenile prosecutors and judges (In fact during the researching period juvenile judges and prosecutors at country level have resolved criminal cases in juvenile criminal cases through diversity measures application in about $25 \%$ of cases), or the fact that they prefer the application of diversity measures, some of which are very similar to mediation (Annual statistical,..). Therefore, I consider in the future Kosovo juvenile judges and prosecutors should apply this mediation institute of criminal case resolution more often (in all cases when legal terms are met) always by bearing in mind benefits realized by this alternative procedure the state and the parties. Of course in order for this to happen, it is required to work harder on professional performance of juvenile judges and prosecutors, because in this way the state and criminal procedural parties easier manifest their interest in criminal proceedings.

\section{Conclusion}

Modest results of this scientific paper led me to these conclusions:

Mediation in juvenile criminal proceedings is a law institute which enables the alternative resolution of a criminal case between juvenile and the injured party outside of court. Through application of this institute is made possible the resolution of criminal case without having the need to conduct criminal proceedings.

By Kosovo Juvenile Justice Code there are no restrictions concerning the type of criminal offences for which mediation may be authorized. This means that mediation may be authorized for any type of criminal offences if it is considered to be appropriate by taking into account the nature of criminal offence, the circumstances of its commission, the history of juvenile, the possibility of returning normal relationships between the juvenile and the injured party, the possibility of reducing the harm of the injured party and the possibility of rehabilitating the minor and reintegrating him into society.

Obviously, the application of mediation procedure is not considered appropriate for serious criminal offenses such as murders, and when they are committed in aggravating circumstances.

The competence to initiate mediation institute in juvenile criminal proceedings belongs to the minor, the injured party, the state prosecutor, and the juvenile judge. Whereas, the competence to refer the criminal case to mediation procedure belongs only to juvenile judge and prosecutor. Mediation shall be conducted by an independent mediator and the latter as a third party helps juvenile and the injured party to achieve an agreement and reconciliation. He has in his disposal a period of time of 30 days, as well as has the authority to undertake 
concrete measures to ensure that the content of agreement to be proportionate with the seriousness and consequences of the criminal offence. The mediator is entitled to propose alternatives and ideas on how to resolve a criminal case, but it should be emphasized the fact that parties are independent in terms of deciding concerning the case. The mediator is obliged to notify juvenile judge or prosecutor as for reaching an agreement as well as the failure to do so. In case of reaching an agreement the criminal proceedings shall be terminated, whereas in case of failure to reach an agreement the criminal proceedings shall resume where it has been suspended.

Criminal case resolution through mediation manifests significant effects for parties as well as for public interest. Through application of this institute is affected in reduction of juvenile criminal cases in courts and prosecutions waiting addressing and settlement, low of public expenditures, raise the level of social responsibility, educating minors with the feeling of seeking forgiveness and compensation damage and cooperation with the criminal procedure bodies, cases of vigilantism are eliminated etc.

During the research of Kosovo basic courts and prosecutions work has been ascertained that during the period of time 2013-2017 they have referred for mediation procedure 59 criminal cases, of which independent mediators have reached an agreement between parties in 23 cases. As it results mediation procedure has failed in 36 cases that could be as a result of mediators lack of experience based on the fact many of them belong to the young generation of lawyers but also because they do prefer to impose diversity measures for the big number of cases which could have been addressed for resolution to mediation procedure.

It is worrying that juvenile judges and prosecutors during the period of time 2013-2017 have addressed for mediation procedure only $0.50 \%$ of criminal cases, in terms when legal and practical possibilities for such referral have been bigger. Therefore, by Kosovo judges and prosecutors, by bearing in mind the great importance mediation procedure has, it is required this institute in the future to be more often applicable. In this regard, it is required for Kosovo juvenile judges and prosecutors to be developed respective training programs that would enable and motivate them for more frequent application of this institute.

\section{References}

Elezi, I. (2004a). Mediation for Reconciliation in Criminal Disputes (2nd ed.), University of Tirana, Tiran.

Elezi, I. (2015b). Restoration Justice for Juveniles in Conflict with Law (1st ed.), European University of Tirana, Tirana.

Hajdari, A. (2010c). Criminal Procedure, Commentary (1st ed.), College FAMA, Pristina.

Hajdari, A. (2013e). Criminal Procedure Law, Special Part, College ILIRIA, Pristina.

Hajdari, A. (2016a). Code of Criminal Procedure, Commentary (1st ed.), College FAMA, Prishtina.

Hajdari, A. (2016b). Criminal case resolution at the hearing of the indictment - Kosovo Context. Lexkhoj International Journal of Criminal Law, 2(1).

Hajdari, A. (2016d). Conditional Release of Convicted Persons in Kosovo. International Journal of Research in Humanities and Social Studies, 3(7), 32-39. 


\section{Macrothink}

International Journal of Social Work

ISSN $2332-7278$

2018, Vol. 5, No. 1

Hajdari, A., \& Krasniqi, M. (2012). Mediation as a New Approach to Alternative Dispute Resolution, Advocacy, Kosovo Chamber of Advocates Bulletin, No. 13, Pristina, 129-130.

Latifi, V., Elezi, I., \& Hysi, V. (2012). Crime Combating Policy (1st ed.), College JURIDICA, Pristina.

Law on Courts (Law No. 03 / L-199).

Law on Mediation (Law No.03 / L-057).

Milutinoviq, M. (1984). Criminal Policy (2nd ed.), University of Prishtina, Pristina.

Pavišić, B., Vučković, M., Veić, P., \& Radolović, A. (1998). Zakon o kaznenom postupkus'komentarom, literaturom i sudskom praksu (2nd ed.), University of Zagreb, Zagreb.

Registers of Kosovo Mediation Centers for the period 2013-2017.

Resolution of the General Assembly No 40/33 of 29 November 1985.

Resolution of the General Assembly No. 30/1997 of 1997.

Resolution of the General Assembly No.45 / 113 of 14 December 1990.

Resolution of the General Assembly, No. 45/112 of 14 December 1990.

Sahiti, E. (1999). Argumentation in Criminal Procedure (3rd ed.), University of Pristina, Pristina.

Sahiti, E., \& Murati, R. (2015). Criminal Procedure Law (1st ed.), University of Pristina, Pristina.

Sahiti, E., Murati, R., \& Elshani, X. (2014). Criminal Procedure Code of the Republic of Kosovo, Commentary (1st ed.), GTZ- Pristina, Pristina.

Shegani, A. (2014). Mediation Service and Restorative Justice for Juveniles in Conflict with the Law (1st ed.), University of Tirana, Tirana.

\section{Copyright Disclaimer}

Copyright reserved by the author(s).

This article is an open-access article distributed under the terms and conditions of the Creative Commons Attribution license (http://creativecommons.org/licenses/by/3.0/). 